\title{
Implementasi Perda No. 09 Tahun 2002 Tentang Penataan dan Penertiban Pedagang Kaki Lima di Kota Pasuruan
}

\author{
Aminullah, M. Irfan Islamy, M. R. Khairul Muluk \\ Mahasiswa Program Magister Ilmu Administrasi Publik Fakultas Ilmu Administrasi \\ Dosen Program Magister IImu Administrasi Publik Fakultas IImu Administrasi \\ Dosen Program Magister Ilmu Administrasi Publik Fakultas IImu Administrasi
}

\begin{abstract}
Abstrak
Meningkatnya jumlah PKL di pusat pertumbuhan ekonomi dan di pusat-pusat perkotaan sekarang ini menjadi masalah yang urgen untuk diperhatikan. Keberadaan mereka acapkali dinilai sebagai faktor penghambat program tata letak dan tata ruang kota yang dilakukan oleh kebanyakan pemerintah daerah di Indonesia. Perspektif yang muncul akibat adanya PKL menuntut pemerintah daerah untuk membuat suatu kebijakan yang nantinya diharapkan menjadi penengah dengan beberapa kepentingan yang ada. Produk kebijakan ini akan terwujud jika dalam proses kebijakan yang akan dibuat oleh pemerintah harus melibatkan masyarakat umum, terutama pelaku usaha Informal yakni PKL baik secara individual, perwakilan bahkan organisasi yang terbentuk dalam PKL tersebut. Penelitian ini menggunakan metode kualitatif dengan tujuan mendeskripsikan, menganalisis dan menginterpretasikan proses dan mekanisme, aktor, dan faktor pendukung dan penghambat implementasi Perda No. 09 Tahun 2002 tentang Penataan dan Penertiban Pedagang Kaki Lima di Kota Pasuruan. Penelitian ini dilakukan di Kota Pasuruan. Teknik pengumpulan data yang digunakan adalah wawancara mendalam, observasi, dan dokumentasi. Analisis data yang digunakan dengan menggunakan pendekatan linear dan hierarkis dari atas kebawah. Hasil penelitian menunjukkan proses dan mekanisme implementasi Perda No. 09 Tahun 2002 tentang penataan dan penertiban PKL di Kota Pasuruan terdapat tahapan-tahapan mekanisme yang masing-masing tahapan mempunyai tujuan dan target yang berbeda.
\end{abstract}

Kata Kunci : Kebijakan Publik, Implementasi Kebijakan, Pedagang Kaki Lima

\section{Abstract}

The increasing number of street vendors in the center of economic growth and in urban centers is now an urgent issue to be considered. Their presence is often regarded as obstacles in program and spatial layout of the city by most local governments in Indonesia. Perspective arising from street vendors requires local governments to create a policy that will be expected to mediate with some interest there. Products of this policy will be realized if the policy process that will be made by the government to involve the general public, especially businesses that informal street vendors individually, even representatives of organizations that formed in the street vendors.

This research uses qualitative methods with the aim to describe, analyze and interpret the processes and mechanisms, actors, and factors supporting and inhibiting the implementation of Regulation No. 09 of 2002 on Structuring and Control of Street Vendors in Pasuruan. This research was conducted in Pasuruan. Data collection techniques used are in-depth interviews, observation, and documentation. The results show the process and implementation mechanisms by law No. 09 of 2002 on structuring and regulating street vendors in Pasuruan there are stages mechanisms each stage has different objectives and targets.

Keywords: Public Policy, Policy Implementation, Street Vendors

\section{PENDAHULUAN}

Adanya ketimpangan sosial dan kemiskinan yang disebabkan oleh pembangunan dalam perspektif ekonomi politik dapat diterjemahkan

Korespodensi :

Aminullah

Email : aminullahmajid@gmail.com

Alamat : Jl. Perintis No. 23 Madurejo Wonorejo

Pasuruan 67173 sebagai hasil dari proses yang mendorong konsentrasi kekayaan dan kekuasaan di satu pihak dan menumbuhkan masyarakat pinggiran yang memiliki daya tawar lemah terhadap pihak lain.

Permasalahan kemiskinan merupakan masalah klasik yang dihadapi oleh semua negara, terutama negara-negara sedang berkembang. Kemiskinan di negara berkembang umumnya disebabkan oleh 
keterbelakangan pendidikan, minimnya pengembangan sumber daya alam dan manusia yang dimiliki serta ketidaktepatan strategi dan program pembangunan yang diterapkan dan yang paling penting adalah faktor ketidakmerataan pendidikan dan akses informasi.

Sedangkan dari sudut pandang sosial ekonomi, bisa dianggap sebagai akibat dari sistem filterisasi yang ada dalam masyarakat, dimana struktur sosial telah berkembang begitu pesat dengan sendirinya sehingga menghambat Pengelompokan Pedagang Kaki Lima (PKL) berdasarkan karakteristiknya bisa dilihat dari berbagai aspek:

1. Aspek ekonomi: PKL merupakan kegiatan konomi skala kecil dengan modal relatif minim. Aksesnya terbuka sehingga mudah dimasuki usaha baru, konsumen lokal dengan pendapatan menengah kebawah, teknologi sederhana/tanpa teknologi, jaringanusaha terbatas, kegiatan usaha dikelola satu orang atau usaha keluarga dengan pola manajemen yang relatif tradisional. Selain itu, jenis komoditi yang diperdagangkan cenderung komoditi yang tidak tahan lama seperti makanan dan minuman.

2. Aspek Sosial-budaya: sebagian besar pelaku berpendidikan rendah dan migran (pendatang) dengan jumlah anggota rumah tangga yang besar. Mereka juga bertempat tinggal di pemukiman kumuh.

3. Aspek Lingkungan: kurang memperhatikan kebersihan dan berlokasi ditempat yang padat lalu lintas [1].

Menjamurnya PKL di pusat pertumbuhan ekonomi dan di pusat-pusat perkotaan sekarang ini menjadi masalah yang urgen untuk diperhatikan. Keberadaan mereka acapkali dinilai sebagai faktor penghambat program tata letak dan tata ruang kota yang dilakukan oleh kebanyakan pemerintah daerah di Indonesia. Diantaranya keberadaan mereka dianggap sebagai pengganggu fasilitas publik, memakai hak publik dalam hal trotoar jalan atau yang lebih kita kenal dengan istilah kembang trotoar.

Fenomena pertumbuhan PKL telah menjadi isu internasional karena menimbulkan potensi konflik penataan ruang yang akan berdampak negatif bagi ketertiban dan keindahan kota. Konflik ruang yang ditimbulkan oleh PKL jika
PKL sudah menempati ruang publik kota pada suatu kawasan tertentu sehingga mengakibatkan terganggunya fungsi ruang publik tersebut. Kasus yang umum terjadi adalah terganggunya fungsi trotoar sebagai tempat pejalan kaki dan fungsi jalan sebagai tempat laju kendaraan bermotor. Dalam kaitan inilah maka upaya penataan Pedagang Kaki Lima menjadi sangat penting dilakukan sebagai bagian dari penataan ruang kota untuk menjamin terwujudnya ketertiban dan kenyamanan kota.

Perspektif yang muncul akibat adanya Pedagang Kaki Lima diatas seakan-akan menuntut pemerintah daerah untuk membuat suatu kebijakan yang nantinya diharapkan menjadi penengah dengan beberapa kepentingan yang ada. Produk kebijakan ini akan terwujud jika dalam proses kebijakan yang akan dibuat oleh pemerintah dan harus melibatkan masyarakat umum, terutama pelaku usaha Informal yakni Pedagang Kaki Lima baik secara individual, perwakilan bahkan organisasi yang terbentuk dalam Pedagang Kaki Lima tersebut.

Pemerintah dalam hal ini menjadi tempat sandaran masyarakat secara umum, diharapkan mampu mengatasi permasalahan masyarakat yang sangat kompleks, disatu sisi pemerintah juga dituntut untuk bisa mengembangkan perkotaan kearah yang lebih baik. Keberadaan PKL menjadi salah satu penghambat pemerintah dalam hal megembangkan tata ruang dan tata wilayah perkotaan. Banyak contoh-contoh Pemerintah Daerah di Indonesia yang memproduk kebijakan dalam kaitannya penataan, penertiban serta pemberdayaan PKL. Tetapi dalam kenyataannya masih terdengar disana-sini terjadi konflik antara pemerintah dan PKL setempat, misalnya penggusuranpenggusuran yang dinilai kurang manusiawi, relokasi PKL yang tidak sesuai dengan keinginan para PKL.

Di berbagai daerah, implementasi kebijakan penertiban dan relokasi PKL sering terjadi kekisruhan, bila dilihat lebih jauh model pendekatan penertiban dan relokasi tersebut, lebih tepat disebut sebagai penggusuran dengan alasan keberadaan PKL yang semrawut atau tidak teratur, mengganggu ketertiban, keindahan serta kebersihan lingkungan kota. Kemudian lokasi PKL yang sembarangan bahkan 
cenderung menggunakan bibir jalan yang sangat mengganggu lalu lintas, baik bagi pejalan kaki maupun pengendara motor atau mobil. Selain itu, parkir kendaraan para pembeli yang tidak teratur, juga sangat mengganggu ketertiban. Belum lagi masalah limbah atau sampah yang berserakan di sekitar tempat ia berjualan.

Perkembangan PKL di kota Pasuruan sangat pesat sekali, hal ini diakibatkan kurangnya lapangan pekerjaan di desa, akhirnya banyak orang-orang berbondong-bondong melakukan urbanisasi ke kota dengan alasan mencari penghidupan yang lebih layak. Faktor lain diakibatkan dari banyaknya orang-orang yang di PHK dari perusahaan yang pada akhirnya PKL sebagai pilihan lapangan pekerjaan dengan alasan Usaha PKL dinilai tidak rumit dan sangat memungkinkan orang-orang untuk tetap bisa hidup dalam menopang perekonomiannya.

Kondisi Pedagang Kaki Lima di kota Pasuruan saat ini belum sepadat kota-kota besar di Indonesia. Namun, kecenderungan jumlah Pedagang Kaki Lima setiap tahunnya selalu meningkat. Walaupun demikian, penataan Pedagang Kaki Lima harus segera dilakukan karena ada kecenderungan seperti Alun-alun, Taman Kota Pasuruan dan Sekitar JI. Sudirman diperkirakan akan bertambah, terutama disekitar alun-alun yang merupakan pusat tujuan wisatawan religi.

Keberadaan Pedagang Kaki Lima di kota Pasuruan terutama Pedagang Kaki Lima yang berada di sekitar Kota Pasuruan sudah dinilai sangat memprihatinkan karena keberadaan mereka mengakibatkan banyak faktor negatif, diantaranya mengganggu lancarnya lalu lintas, buruknya pandangan kota karena mereka cenderung bikin kumuh dan kotor sehingga berimbas pada kondisi kota yang tidak sedap dipandang. Pada sudut yang berbeda ada hal positif yang ditimbulkan dengan keberadaan mereka diantaranya, masyarakat lebih mudah mendapatkan kebutuhan konsumsi yang murah, secara tidak langsung juga dengan keberadaan mereka menyumbang pendapatan asli daerah Kota Pasuruan.

Dari Latar belakang diatas penelitian ini dimaksudkan untuk mengetahui, menganalisis dan menginterpretasi peraturan daerah tentang penataan dan penertiban Pedagang Kaki Lima di Kota Pasuruan.

\section{METODE PENELITIAN}

Penelitian ini menggunakan metode penelitian kualitatif dengan pendekatan fenomenologi. Dalam penelitian fenomenologi melibatkan pengujian yang teliti dan seksama pada kesadaran pengalaman manusia.

Menurut Smith konsep utama dalam fenomenologi adalah makna. Makna merupakan isi penting yang muncul dari pengalaman kesadaran manusia. Untuk mengidentifikasi kualitas yang essensial dari pengalaman kesadaran dilakukan dengan mendalam dan teliti [10]. Manfaat pendekatan ini ditujukan untuk mempelajari fenomena sosial dengan tujuan menjelaskan dan menganalisa perilaku manusia dan kelompok, dari sudut pandang yang sama sebagai objek yang diteliti melihat masalah tersebut. Metode kualitatif dapat digunakan untuk menemukan dan memahami apa yang tersembunyi dibalik fenomena yang kadangkala merupakan sesuatu yang sulit untuk diketahui dan difahami.

Pendekatan ini digunakan untuk mengungkapkan bagaimana Implementasi Peraturan Daerah No. 09 Tahun 2002 Tentang Penataan dan Penertiban Pedagang Kaki Lima di Kota Pasuruan.

\section{Metode Pengumpulan Data}

Data yang terhimpun dianalisis dengan menggunakan pendekatan linear dan hierarkis dari atas kebawah yang meliputi pembacaan keseluruhan data, pengolahan data, Coding, setting orang-orang, kategori-kategori dan tema-tema yang akan di analisis, mendeskripsi dalam narasi, dan menginterpretasi atau memaknai data.

\section{HASIL DAN PEMBAHASAN}

Setelah Kebijakan negara itu dirumuskan proses selanjutnya adalah bagaimana memulai proses implementasi, yang bersifat interaktif dari proses kegiatan yang mendahuluinya. Ini berarti antara perumusan kebijakan dan implementasi kebijakan saling memiliki ikatan satu sama lain.

Proses Implementasi Perda No. 09 tahun 2002 tentang penataan dan penertiban pedagang kaki lima di Kota Pasuruan tidak serta merta dilaksanakan di lapangan secara langsung, akan tetapi membutuhkan sebuah proses mekanisme pelaksanaan dengan tujuan 
implementasi tersebut bisa tepat sasaran dan sesuai dengan tujuan yang dicita-citakan. Mekanisme pelaksanaan ini sangat penting peranannya karena jika dalam implementasi Perda tidak terdapat beberapa tahapan mekanisme dikhawatirkan akan terjadi hal-hal yang tidak diinginkan seperti resistensi PKL yang bisa saja menjadi konflik antara PKL dengan aktor kepentingan aktor lain di lapangan.

Proses mendeskripsikan, menganalisis dan menginterpretasikan proses dan mekanisme, aktor, dan faktor pendukung dan penghambat implementasi Perda No. 09 Tahun 2002 tentang Penataan dan Penertiban PKL di Kota Pasuruan, peneliti menggunakan model implementasi yang dikembangkan oleh Edward III (1980)[11]. Model ini mengisyaratkan bahwa keberhasilan implementasi ditentukan oleh communication (komunikasi), resource (sumberdaya), disposition (disposisi) or attitudes, dan bureaucratic (birokrasi).

Proses dan Mekanisme Sosialisasi Perda No. 09 Tahun 2002 Tentang Penataan dan Penertiban PKL di Kota Pasuruan

Proses Implementasi Perda No. 09 tahun 2002 tentang penataan dan penertiban pedagang kaki lima di Kota Pasuruan tidak serta merta dilaksanakan di lapangan secara langsung, akan tetapi membutuhkan sebuah proses mekanisme pelaksanaan dengan tujuan implementasi tersebut bisa tepat sasaran dan sesuai dengan tujuan yang dicita-citakan.[12]

Salah satu kegiatan yang dilakukan oleh Pemerintah Daerah dalam menertibkan, mengelola dan mengembangkan daerahnya adalah membuat Peraturan Daerah (Perda) sesuai dengan bidang yang mencakup seluruh aspek kehidupan daerah tersebut.

Dalam upaya menciptakan ketertiban dan keamanan Kota Pasuruan, maka disusunlah Peraturan daerah yang membahas mengenai keberadaan dan penataan Pedagang Kaki Lima di Kota Pasuruan. Perda ini masih bersifat sangat umum mengenai aturan ideal teknis pengaturan PKL. Ketentuan khusus, tata cara teknis pelaksanaan kegiatan akan diperjelas dalam Peraturan Walikota.

Maksud dari adanya Perda ini adalah untuk mengatur, menata, dan membina PKL di daerah Kota Pasuruan. Sementara tujuan dari Perda ini adalah untuk menciptakan Kota Pasuruan yang aman, bersih, dan tertib, serta memantapkan Kota Pasuruan sebagai kota tujuan wisata.

\section{Komunikasi (Communication) dalam Implementasi Perda Penataan dan Penertiban Pedagang Kaki Lima di Kota Pasuruan}

Komunikasi dalam implementasi Perda No 09 Tahun 2002 ini dilakukan dengan cara sosialisai kepada objek kebijakan. Terdapat dua bentuk sosialisasi, yakni sosialiasi langsung dan sosialisasi tidak langsung.

Sosialisasi dalam implementasi kebijakan merupakan sebuah proses yang mengandung penyaluran informasi substansi Perda kepada sasaran objek dari Perda tersebut, sekaligus informasi tersebut bertujuan kepada masyarakat secara umum. Penyebarluasan informasi sangat penting dilakukan mengingat pentingnya sebuah peraturan diketahui oleh sasaran baik individu maupun kelompok.

a. Sosialisasi Langsung

Bentuk sosialisasi langsung adalah suatu kegiatan yang dilakukan oleh Dinas Koperasi Perindustrian dan Perdagangan melalui seksi perdagangan dengan cara mengundang perwakilan-perwakilan Pedagang Kaki Lima melalui paguyuban-paguyuban berdasarkan lokasi atau kawasan yang telah ditentukan oleh Pemerintah Daerah Kota Pasuruan, dalam proses sosialisasi ini Dinas Koperasi Perindustrian dan Perdagangan juga mengundang ketua-ketua pengelola pasar untuk menjelaskan aturan main, kewajiban, larangan dan himbauan-himbauan yang terdapat pada Perda No. 09 Tahun 2002. Selain penjelasan tentang Perda No. 09 Tahun 2002 ini, Diskoperindag juga meminta kerja sama dengan paguyuban PKL untuk meneruskan informasi Perda kepada anggotanya masingmasing. Kerjasama antara Diskoperindag dan ketua paguyuban bertujuan menyampaikan informasi kepada anggotanya masing-masing, hal ini merupakan kegiatan sosialisasi awal yang nantinya akan ditindak lanjuti dengan beberapa penyampaian informasi kepada seluruh Pedagang Kaki Lima yang berada di Kota Pasuruan dengan sosialiasi tidak langsung. b. Sosialisasi Tidak Langsung

Sosialisasi Perda No. 09 Tahun 2002 bukan hanya dilakukan dengan sosilisasi langsung, agar Perda tersebut cepat diketahui oleh 
masyarakat PKL dan sesuai dengan tujuan yang diinginkan maka Dinas Koperasi Perindustrian dan Perdagangan Pemerintah Kota juga menggunakan sosialisasi Perda secara tidak Langsung. Bentuk sosialisasi tidak langsung yang dilakukan oleh Dinas Koperasi Perindustrian dan Perdagangan adalah melalui media cetak (koran) dan spanduk. Bentuk sosialisasi ini bertujuan memperluas infomasi keberadaan Perda No. 09 Tahun 2002 tentang Penataan dan Penertiban Pedagang Kaki Lima di Kota Pasuruan.

Sumberdaya (Resources) Implementasi Perda Penatan dan Penertiban PKL di Kota Pasuruan

Keberhasilan implementasi kebijakan sangat tergantung dari kemampuan memanfaatkan sumberdaya yang tersedia. Sumberdaya tersebut dapat berupa manusia, finansial, dan waktu.

Sumberdaya merupakan aspek penting bagi implementasi penataan dan penertiban PKL di Kota Pasuruan yang efektif. Dalam implementasi perda penataan dan penertiban PKL di Kota Pasuruan terdapat beberapa sumberdaya atau aktor pelaksana perda tersebut, diantaranya Pemerintah Kota yang dikorrdinir oleh Diskoperindag meliputi jumlah staf yang mempunyai keterampilan yang memadai serta dengan jumlah yang cukup, kewenangan, informasi dan fasilitas, SatPol PP selaku penegak Perda sera PKL itu sendiri. Disamping itu, perlu pula memperhatikan aspek sumberdaya finansial, sumberdaya waktu dan dibingkat dengan koordinasi yang efektif dalam pelaksanakaan program, akan sangat memungkinkan program dapat terlaksana sesaui denga tujuan kebijakan itu sendiri.

\section{Disposisi Birokrasi dalam Implementasi Perda Penataan dan penertiban PKL di Kota Pasuruan}

Kebijakan publik mempengaruhi setiap warga negara dengan berbagai cara, sebagian dari mereka kadang akrab dengan Kebijakan dan sebagian kecil dari mereka merasa tidak akrab dengan suatu produk kebijakan.

Sikap penerimaan dan penolakkan agen pelaksana akan sangat banyak mempengaruhi keberhasilan atau tidaknya suatu kinerja implementasi kebijakan publik. Sikap pelaksana ini berkaitan dengan seberapa demokratis, antusias, dan responsif terhadap kelompok sasaran dan lingkungan.

Terkadang dalam pelaksanaan kebijakan dilapangan sering kali dijumpai sikap para pelaksana yang menimbulkan hambatanhambatan terhadap implementasi, contoh pejabat atau staf yang tidak melaksanakan kebijakan yang diinginkan oleh atasan. Untuk mengatasi persoalan ini, pemilihan dan pengangkatan para pelaksana kebijakan harus memilih orang-orang yang mempunyai loyalitas dan komitmen terhadap kebijakan yang telah di tetapkan.

Oleh sebab para pelaksana sangat penting dalam implementasi kebijakan, maka usaha untuk memperbaiki peran mereka menjadi penting yang dilakukan melalui pemberian insentif sebagai upaya untuk memenuhi kepentingan pribadi atau organisasi. Meskipun seringkali juga terjadi persoalan menyangkut penentuan tingkat-tingkat insentif, yakni bagaimana dengan adanya insentif diharapkan tujuan bisa dicapai. Untuk itu, dalam penggunaan insentif harus mengukur pencapaian tujuan dari kebijakan yang ditetapkan.

\section{Struktur Birokrasi (Bureaucratic Structure) dalam Implementasi Penataan dan Penertiban PKL di Kota Pasuruan}

Struktur organisasi sebagai pelaksana kebijakan sangat berpengaruh dalam proses implementasi. Salah satu aspek struktural yang yang paling fundamental dari suatu organisasi adalah prosedur-prosedur kerja ukuran dasarnya, yang sering dimaknai sebagai Standard Operating Procedure (SOP). Prosedur biasanya dalam menanggulangi keadaankeadaan umum yang digunakan dalam organisasi-organisasi (baik publik maupun swasta). Dengan menggunakan SOP, para pelaksana dapat memanfaatkan waktu yang tersedia. Selain itu, SOP juga menyeragamkan tindakan-tindakan dari para pejabat dalam organisasi-organisasi yang kompleks dan tersebar luas, yang pada gilirannya dapat menimbulkan fleksibilitas yang besar dan kesamaan yang besar dalam penerapan peraturan-peraturan.

Dalam implementasi penataan dan penertiban PKL di Kota Pasuruan struktur birokrasi pelaksana masing-masing mempunyai 
aturan dan mekanisme sendiri. Diskoperindag sebagai pengayom PKL melakukan kegiatankegiatan yang dibentuk dalam sebuah perda, Satpol PP selaku penegak Perda melakukan tugasnya dengan memakai mekanisme yang mereka miliki sendiri serta PKL sebagai objek Perda bisa melakukan kegiatannya dengan tetap mengindahkan peraturan yang ada.

Faktor Pendukung Implementasi Kebijakan Perda Penataan dan Penertiban Pedagang Kaki Lima (PKL) di Kota Pasuruan

Peraturan Daerah No. 09 Tahun 2002 dalam pelaksanaannya tidak terlepas dari faktor-faktor penghambat dan pendukung dalam proses pelaksanaannya. Suatu produk kebijakan pasti ditemukan siapa diuntungkan dan siapa yang dirugikan, masing-masing untung dan rugi mucul suatu masalah atau faktor baru, jika orang/individu ataupun kelompok yang merasa diuntungkan pasti akan melakukan dukungan terhadap kebijakan terebut, begitu juga sebaliknya, jika orang, individu atau kelompok jika merasa dirugikan pasti akan melakukan sikap/tindakan yang mengarah kegiatan yang mengarah pada sikap ketidak setujuan terhadap keberadaan Perda tersebut.

Implementasi Perda merupakan suatu kegiatan interaktif antara subyek dan obyek dari Perda tersebut, sebagai konsekuensinya muncul beberapa faktor yang bisa saja mendukung atau bahkan muncul faktor-faktor yang menjadi penghambat dalam pelaksanaan sebuah Perarutan Daerah. Demikian halnya Peraturan Daerah No. 09 Tahun 2002 dalam pelaksanaannya tidak terlepas dari faktorfaktor penghambat dan pendukung. Masingmasing faktor itu muncul disebabkan beberapa indikator yang berkaitan di dalamnya.

Faktor pendukung dan penghambat suatu implementasi kebijakan berimplikasi secara nyata terhadap kesuksesan atau kegagalan suatu kebijakan. Howlett dan Ramesh (Suharto, 2011: 36) mencatat bahwa implementasi kebijakan sangat dipengaruhi oleh hakekat dan perumusan masalah kebijakan itu, keragaman masalah yang ditangani oleh pemerintah, ukuran kelompok sasaran, dan tingkat perubahan perilaku yang diharapkan. [13]
Faktor-faktor yang diidentifikasi menjadi faktor pendukung dalam pelaksanaan Implementasi Perda diantaranya :

1. Terjalinnya Komunikasi dan Koordinasi yang baik antar aktor.

Komunikasi sangat penting peranannya bagi keberlangsungan implementasi suatu perda. Komunikasi antar aktor dalam pelaksanaan Perda No. 09 Tahun 2002 sudah terjalin harmonis. Komunikasi yang terjalin antara lain:

a. Antara Diskoperindag dan Satpol PP

Satpol PP dan Diskoperindag telah melakukan komunikasi harmonis dalam rangka penertiban PKL di Kota Pasuruan, dalam melakukan operasi satpol PP melakukan sinergitas dengan Diskoperindag sesuai dengan isi Perda tentang PKL. Komunikasi yang terbangun antara kedua aktor implementasi Perda ini sangat penting peranannya, Diskoperindag selaku koordinator melakukan kerjasama dengan Satpol PP dengan berbagai cara diantaranya rapat bersama dengan Satpol PP dalam rangka sosialisasi segala bentuk peraturan tentang penertiban Pedagang Kaki Lima, mekanisme pengaturan tempat dan alokasi waktu diperbolehkannya PKL melakukan kegiatan usahanya. Fungsi komunikasi diantara keduanya secara keseluruhan bertujuan untuk pemahaman bersama tentang penataan dan penertiban PKL demi terwujudnya situasi dan kondisi yang harmonis antar kepentingan yang ada.

b. Antara Diskoperindag dan Pedagang Kaki Lima

Bangunan komunikasi juga dilakukan oleh Diskoperindag dengan Pedagang Kaki Lima, komunikasi itu antara lain dilaksanakan pada waktu sosialisasi, koordinasi, serta rapat-rapat yang membahas segala sesuatu tentang Pedagang Kaki Lima di Kota Pasuruan. Komunikasi yang dilakukan Pemerintah Kota Pasuruan dengan Pedagang Kaki Lima dilakukan secara terus menerus beerdasarkan secara formal ataupun secara informal. Diskoperindag melakukan komunikasi dengan PKL dengan berbagai macam cara, diantaranya mereka diundang rapat ke Kantor Dinas dalam rangka koordinasi berkaitan dengan penataan dan penertiban pedagang kaki lima, sosialisasi peraturan, bahkan mereka PKL berhak menyampaikan usulannya terkait penataan dan penertiban pedagang kaki lima. 
c. Antara Satpol PP dengan Pedagang Kaki Lima

Selain komunikasi antara Diskoperindag dan PKL, Diskoperindag dengan Satuan Polisi Pamong Praja (Satpol PP), ada komunikasi lain yang juga tidak kalah pentingnya dalam Proses Implementasi Perda No. 09 Tahun 2002 yakni komunikasi antara pedagang kaki lima dengan Satuan Polisi Pamong Praja. Komunikasi ini dibangun dengan tujuan terhindarnya bentrok antara Satpol PP selaku penegak terlaksananya Perda dengan Pedagang Kaki Lima.

Ada 3 mekanisme komunikasi yang dibangun diantara PKL dengan Satpol PP : pertama Patroli Keliling, himbauan adalah proses komunikasi yang dilakukan oleh Satuan Polisi Pamong Praja kepada PKL pada waktu pelaksanaan penertiban PKL di lapangan, kegiatan ini dilakukan dengan cara patroli keliling pada tempat-tempat dimana PKL dilarang menggelar dagangannya. Kedua Peringatan, Peringatan ini dilakukan oleh Satpol PP kepada PKL yang yang tidak mengindahkan himbauan yang diberikan oleh Satpol PP pada waktu pelaksanaan patroli keliling. Peringatan yang dimaksud disini adalah sebuah komunikasi yang dilakukan oleh Satpol PP dengan memakai bahasa-bahasa peringatan dan ancaman akan dilakukan penindakan jika PKL masih saja tidak mengindahkan peringatan yang diberikan. Ketiga Penindakan, Penindakan ini dilakukan oleh Satpol PP dengan cara merampas barang dagangan, gerobak yang kemudian dibawa ke kantor Satpol PP untuk proses penegakan peraturan.

Dalam kegiatan penindakan ini dilakukan dengan tiga tahapan pertama, barang dagangan PKL dirampas kemudian PKL boleh membawa barang dagangan, gerobak yang dirampas oleh Satpol PP dengan berjanji tidak melakukan pelanggaran yang sama. Kedua, jika masih melakukan pelanggaran yang sama, maka PKL harus menandatangani surat perjanjian bermaterai dengan harus menanggung konsekuensi jika tetap melakukan pelanggaran yang sama maka tahapan ketiga akan dilakukan perampasan permanen dan PKL tidak bisa mengambilnya lagi. Ketiga, perampasan permanen, hal ini dilakukan karena merupakan konsekuensi PKL setelah penandatanganan surat perjanjian bermaterai.

2. Pemahaman bersama antar aktor terhadap substansi dari Perda.

Perda No. 09 Tahun 2002 tentang Penataan dan Penertiban Pedagang kaki Lima sangat penting dipahami oleh aktor implementasi, baik birokrasi dan PKL, karena tidak akan mungkin peraturan akan dilaksanakan dilapangan jika aktor implementasinya tidak memahami substansi Perda, target dan tujuan dari sebuah Perda tersebut, PKL sendiri juga harus memahami terhadap substansi Perda, karena didalamnya yang menjadi obyek Perda itu tidak ada lain adalah PKL sendiri.

Pemahaman substansi Perda PKL ini bertujuan mewujudkan harmonisasi antar kepentingan, kepentingan birokrasi yaitu bagaimana menjaga kenyamanan dan ketertiban kota serta menjaga kesan keasrian Kota dari kesemrautan dan kekumuhan. Pemahaman akan substansi Perda No. 09 Tahun 2002 ini dilakukan oleh Birokrasi dan PKL dengan berbagai bentuk, salah satunya adalah komunikasi, suatu program hanya dapat dilaksanakan dengan baik apabila jelas bagi para pelaksana. Hal ini menyangkut proses penyampaian informasi, kejelasan informasi dan konsistensi informasi yang disampaikan. Salah satu sarat keberhasilan dalam Implementasi kebijakan adalah Komunikasi, komunikasi dalam hal ini dimaksudkan bagaimana pengelolaan informasi tentang keberadaan Peraturan untuk semaksimal mungkin sampai pada target. Selain itu diaharapkan dalam komunikasi ini menjalin suatu hubungan yang baik antar individu atau kelompok.

Bentuk pemahaman terhadap substansi Perda yang selanjutnya adalah kemampuan sumber daya manusia yang handal ditingkat internal Diskoperindag, sumber daya manusia meliputi empat komponen yaitu staf, informasi yang dibutuhkan guna pengambilan keputusan, kewenangan yang cukup guna melaksanakan tugas atau tanggung jawab dan fasilitas yang dibutuhkan dalam pelaksanaan. Sumber daya yang dimiliki Diskoperindag masing-masing staf sudah sesuai dengan bidang dan latar belakang pendidikannya. Dengan memiliki Sumber daya manusia yang kompeten dibidangnya akan menghasilkan 
sebuah proses implementasi yang baik di lapangan. Selain itu sumber daya manusia yang lain yang menjadi aktor pelaksana adalah Satpol PP yang juga melalui rekruitmen yang ketat menghasilkan pegawai-pegwai yang tegas dan tanggung jawab. Selain sumber daya manusia, tersedianya fasilitas-fasilitas yang benar-benar memadai sehingga implementasi kebijakan bisa mencapai target yang telah ditentukan. Fasilitas dalam implementasi memegang pengaruh yang sangat dominan karena fasilitas merupakan alat penunjang ssebuah Implementasi yang baik itu akan terwujud.

\section{Faktor Penghambat Implementasi Penataan dan Penertiban PKL di Kota Pasuruan}

Peraturan Daerah No. 09 Tahun 2002 dalam pelaksanaannya tidak terlepas dari faktorfaktor penghambat dalam proses pelaksanaannya. Suatu produk kebijakan pasti ditemukan siapa diuntungkan dan siapa yang dirugikan, masing-masing untung dan rugi muncul suatu masalah atau faktor baru, jika orang/individu ataupun kelompok yang merasa diuntungkan pasti akan melakukan dukungan terhadap kebijakan terebut, begitu juga sebaliknya, jika orang, individu atau kelompok jika merasa dirugikan pasti akan melakukan sikap/tindakan yang mengarah kegiatan yang mengarah pada sikap ketidak setujuan terhadap keberadaan Perda tersebut.

Beberapa faktor yang menjadi penyebab terhambatnya implementasi Perda No. 09 Tahun 2002 antara lain :

a. Kurangnya pengetahuan PKL terhadap keberadaan Perda.

PKL yang berada di Kota Pasuruan memang tidak seluruhnya sudah lama berada di Pasuruan, banyak dari mereka yang masih baru memulai mengadu nasib di Kota Pasuruan untuk menjadi PKL karena diajak oleh saudara atau kerabat dekatnya. PKL yang sudah lama hanya mengerti sebagian kecil dari Perda tersebut, sedangkan PKL yang masih baru hampir tidak mengerti seutuhnya tentang Perda penataan tersebut. Masalah ketidaktahuan PKL terhadap keberadaan Perda itu kebanyakan dialami oleh PKL yang berada di kawasan sekitar alun-alun yang sebenarnya menurut aturan yang berlaku tempat tersebut tidak diperkenankan untuk melakukan kegiatan usahanya.

Ada juga sejumlah PKL yang melakukan kegiatan usaha dipinggir-pinggir jalan sehingga keberadaan mereka sering mengganggu lancarnya arus lalu lintas. Upaya satpol PP untuk menertibkan PKL sering terlontar alasan PKL tidak mengetahui keberadaan Perda PKL, namun alasan sebenarnya berdasarkan hasil penelitian dilapangan adalah faktor perekonomian mereka yang menyebabkan mereka cenderung memaksakan diri untuk melakukan kegiatan usahanya.

b. Bersikerasnya PKL untuk tetap melakukan kegiatan usahanya pada tempat yang dilarang.

Pelaksanaan Implementasi Perda No.09 Tahun 2002 secara umum tidak langsung diterima oleh Pedagang Kaki Lima, satu sisi keberadaan PKL bisa menjadi penyumbang pendapatan daerah dan bagi PKL sendiri usaha informalnya menjadi tulang punggung perekonomian keluarga mereka, pada sisi yang lain jika keberadaan PKL tidak ditertibkan bisa mengganggu keindahan Kota. Pemerintah Kota Pasuruan menertibkan PKL dengan tujuan kedua kepentingan elemen tersebut tetap terjaga. Masalah perekonomian yang menimpa kondisi PKL mengakibatkan PKL bersikeras untuk tetap melaksanakan kegiatannya.

PKL yang dengan bersikeras menginginkan melakukan kegiatan usahanya pada tempat-tempat yang cenderung banyak pengunjungnya, seperti alun-alun Kota Pasuruan, tempat tersebut memang menjadi pusat pertokoan, pembelanjaan dan pengaruh keberadaan makam Kiai Hamid yang mengundang wisatawan religi. PKL yang berada ditempat ini adalah PKL yang tidak memiliki status dibawah komando paguyuban PKL, mereka memakai alat bergerak sebagai sarana berdagangnya agar sewaktu-waktu bisa berpindah tempat dan menghindar dari razia Satpol PP. Keberadaan PKL ditempat ini sering menjadi pemicu macetnya lalu lintas, terkesan merusak kenyamanan pemandangan alun-alun sebagai pusat kota.

Selain PKL yang berada di sekitar alunalun Kota Pasuruan, terdapat PKL yang sering memadati kawasan Parkir wisata, kawasan tersebut menjadi pintu masuk terminal Kota Pasuruan, secara otomatis para penumpang 
menjadi sasaran PKL untuk menjajakan dagangannya. Keberadaan PKL di daerah ini juga sangat menganggu ketertiban lalu lintas, sehingga menimbulkan kemacetan.

\section{KESIMPULAN DAN SARAN \\ Kesimpulan}

Dalam proses dan Mekanisme Implementasi Perda No. 09 Tahun 2002 tentang Penataan dan Penertiban PKL di Kota Pasuruan terdapat tahapan-tahapan mekanisme yang masing-masing tahapan mempunyai tujuan dan target yang berbeda. Tahapan mekanisme yang dimaksud yaitu sosialisasi tentang keberadaan Perda No. 09 Tahun 2002 tentang Penataan dan Penertiban Pedagang Kaki Lima baik secara langsung maupun tidak. Sosialisasi ini merupakan langkah awal dalam rangka membangun sebuah komunikasi harmonis antara implementor Perda dengan PKL, selain itu proses sosialisasi ini juga bertujuan penyampaian informasi kepada PKL tentang Perda penataan dan penertiban PKL di Kota Pasuruan. Dalam Proses sosialisasi ini terdapat dua bentuk sosialisasi, yakni sosialiasi langsung dan sosialiasi tidak langsung.

Faktor pendukung terjalinnya Komunikasi dan Koordinasi yang baik antar aktor, pemahaman bersama antar aktor dan objek terhadap substansi dari Perda. Sedangkan yang menjadi faktor Penghambat adalah kurangnya Pengetahuan PKL terhadap keberadaan Perda, bersikerasnya PKL untuk tetap melakukan kegiatan usahanya.

\section{Saran}

1. Dalam Pelaksanaan Implementasi Perda PKL, Pemerintah harus lebih memaksimalkan penyampaian informasi tentang keberadaan Perda Penataan dan Penertiban PKL agar tidak dijumpai PKL yang masih beralasan tidak mengetahui peraturan yang ada. Dalam pelaksanaan mekanisme sosialisasi Pemerintah Kota Pasuruan diharapkan memiliki cara yang lebih inovatif agar kepentingan Pemerintah dan Pedagang Kaki Lima bisa berjalan selaras tanpa merugikan salah satu pihak.

2. Memberikan penyuluhan, pembinaan dan pelatihan ketrampilan kerja, pengembangan usaha dan pelayanan konsumen sesuai dengan kemampuan, latar belakang dan karakter PKL.

3. Memberikan bantuan modal pada PKL bekerjasama dengan pihak ketiga (swasta, koperasi, BPR, LSM, dsb) untuk pengembangan usaha dan untuk mengikuti program pengembangan usaha.

4. Menjadikan Lokasi-lokasi PKL sebagai pusat jajanan dan kuliner, dengan cara penataan lokasi didesign sedemikian rupa dengan tujuan menarik pengunjung/wisatawan dari luar daerah.

\section{UCAPAN TERIMA KASIH}

Terpublikasinya Jurnal ini tidak terlepas dari sumbang pemikiran dari berbagai pihak. Untuk itu, penulis menyampaikan terima kasih yang mendalam kepada Prof. Dr. M. Irfan Islmy, M.Si selaku Pembimbing Utama dan Dr. MR. Khairul Muluk,MSi selaku Pembimbing Anggota atas kesabarannya dan telah banyak memberikan masukan dalam penulisan jurnal ini.

Terima Kasih yang sama juga penulis sampaikan kepada Ibu Nila Firdausi Nuzula, S.Sos., MS., PhD selaku reviewer sekaligus sebagai Ketua Editor Jurnal WACANA yang sangat teliti dalam mengoreksi serta memberikan banyak catatan perbaikan sehingga jurnal ini menjadi layak untuk diterbikan.

Berbagai pihak yang dengan caranya masing-masing telah membantu penulis merampungkan jurnal ini, dari lubuk hati terdalam penulis ucapkan terima kasih.

Akhirnya, penulis menyadari bahwa jurnal ini masih jauh dari sempurna. Oleh karena itu, kritik dan saran sangat penulis harapkan demi kesempurnaannya. Harapan penulis kiranya jurnal ini dapat memberikan manfaat bagi pembaca sekalian.

\section{DAFTAR PUSTAKA}

[1].Firdausy, C. M. (1995). Model dan Kebijakan Pengembangan Sektor Informal Pedagang Kaki Lima. Pengembangan Sektor Informal Pedagang Kaki Lima di Perkotaan. C. M. Firdausy. Jakarta, Dewan Riset Nasional dan Bappenas Puslitbang Ekonomi dan PembangunanLIPI. Hal : 139-156

[2].Islamy, Irfan. 2001. Seri Policy Analysis. Program PascaSarjana. Malang. 
[3].Smith B, and Larimer C .2009 "The Public policy Theory Primer" by West view Press

[4].Abdul Wahab, Sholicin. 2008. Analisis Kebijkasanaan Dari Formulasi ke Implementasi Kebijaksanaan Negara. Edisi Kedua. Bumi Aksara

[5].Islamy, M. Irfan, 1994, Prinsip-Prinsip Perumusan Kebijakan Negara, Bumi Aksara, Jakarta.

[6].Grindle, Merilee $S$ dan John W. Thomas. 1984. Public Choices And Policy Change: The Political Economy of Reform in Developing Countries.First Edition. John Hopkins University Press. London.

[7].Mazmanian, Daniel A and Paul A. Sabatier. 1983. Implementation and Public Policy, Scott Foresman and Company, USA

[8]. Edward III, George. 1980. Implementing Public Policy. First Edition. CQ Press. USA.

[9].Bromley,R.(1979). Introduction The Urban Informal Sector: Why Is It Worth Discussing? The Urban Informal Sector: Critical Perspectives on Employment and Housing Policies. R. Bromley. Oxford, Pergamon Press: 1031-1032.

[10].Smith, Jonathan A., Flowers, Paul, and Larkin. Michael. 2009. Interpretative phenomenological analysis: Theory, method and research. Los Angeles, London, New Delhi, Singapore, Washington: Sage.

[11].Edward III, George. 1980. Implementing Public Policy. First Edition. CQ Press. USA.

[12].Perda No. 09 Tahun 2002 Tentang Penataan dan Penertiban Pedagang Kaki Lima

[13].Suharto, Edi. 2010. Analisis Kebijakan Publik. Cetakan Kelima. Alfabet. Bandung. 